DOI : $10.14746 /$ rie.2015.9.37

\title{
Polska w Europie 1989-2014. 25 lat po przemianach, red. J. Knopek, M. Sikora-Gaca, D. Magierek, Koszalin 2014.
}

Uroczyście obchodzone 25-lecie wyborów 1989 roku stworzyło idealne warunki, by z perspektywy czasu, przeanalizować obfitujące w polityczne wydarzenia ćwierćwiecze najnowszej historii Polski. Próbę tą podjęli badacze związani z Instytutem Polityki Społecznej i Stosunków Międzynarodowych Politechniki Koszalińskiej. Swoje rozważania zaprezentowali oni w czterech tomach, które poświęcone zostały następującym obszarom: przeobrażeniom społeczno-kulturalnym, przekształceniom gospodarczym, zmianom regionalnym i lokalnym oraz transformacjom politycznym. Lekturę artykułów poprzedza krótkie wprowadzenie, w którym redaktorzy omawiają specyfikę i treść danego tomu.

W poświęconym wybranym aspektom transformacji politycznych tomie, zainteresowany czytelnik odnajdzie artykuły koncentrujące się m.in. na wyzwaniach dla Polski wynikających z uczestnictwa w procesie integracji europejskiej czy definiujące i określające zmianę polskiej polityki zagranicznej w okresie transformacji. Istotną wydaje się konstatacja Piotra Bajora, iż wyłoniony, nowy rząd deklarował aktywny udział Polski w rozwiązywaniu istotnych spraw międzynarodowych zarówno z perspektywy regionalnej i globalnej (s. 26). Syntetyczną analizę, zarówno politologiczną, jak i prawną, Prezydencji w Radzie Unii Europejskiej po traktacie z Lizbony przedstawił z kolei Marek Rewizorski. Stwierdził on, iż traktat z Lizbony wyraźnie poszerzył prezydencję, zmieniając równocześnie jej charakter (s. 63).

Ważnym elementem omawianego tomu są teksty dotyczące relacji Polski z innymi państwami, m.in. z Białorusią, państwami Afryki Zachodniej oraz Chorwacji i Serbii. W odniesieniu do stosunków Polski z Białorusią Autorka słusznie stwierdza, iż jedną z przyczyn je utrudniających jest brak realnego pomysłu strony polskiej na rozwiązanie najpilniejszych problemów. Tematykę artykułów recenzowanego tomu, które w dużej mierze koncentrują się na stosunkach międzynarodowych oraz kwestiach bezpieczeństwa, uzupełniają teksty dotyczące roli Kościoła katolickiego w rozwoju Unii Europejskiej oraz wpływu rozpadu Związku Socjalistycznych Republik Radzieckich na pierwsze lata niepodległości Ukrainy. W próbie określenia współczesnej roli Kościoła katolickiego, Wojciech Stankiewicz podkreśla, iż Stolica Apostolska jest i dalej powinna być aktywnym aktorem sceny europejskiej w kwestiach etycznych i prawnych (s. 153). Czesław Partacz analizując wpływ rozpadu ZSRR na politykę Ukrainy, również w odniesieniu do jej dążeń proeuropejskich, stwierdza, iż jednym z czynników spowalniającym te aspiracje było postrzeganie Ukrainy jako tworu nieobliczalnego, sezonowego, ,siedzącego okrakiem na granicy Wschodu i Zachodu" (s. 117).

Kolejny tom autorzy poświęcili wybranym przykładom obszarów przekształceń gospodarczych. Jest to szczególny obszar badawczy bowiem „,budowa stabilnego otoczenia gospodarczego jest zatem podstawowym elementem kształtującym każdą transformację systemową, jeżeli podąża ona w stronę demokratycznego porządku polityczno-ustrojowego" (s. 5). Artykuły składające się na ten tom omawiają w większości konkretne casusy zmian, które umożliwiła transformacja ustrojowa. Została więc w nim omówiona Wałbrzyska Strefa Ekonomiczna na tle pozostałych tego typu obszarów, przeanalizowano także rozwój energetyki odnawialnej w oparciu o Regionalny Program Operacyjny Województwa Dolnośląskiego. Bardzo interesująco jawią się także rozważania Mirona Kłusaka o kryzysie jako zagrożeniu dla porządku liberalnego oraz wartości demokratycznych. Autor zaznacza w nich, iż społeczność międzynarodowa przedwcześnie „pogrzebała" rolę państwa narodowego. Zauważa dalej, iż to naród musi pilnować swoich interesów i umieć definiować swoje priorytety w jego racji stanu. Cały czas bowiem terytorialność i obywatelskość są ze sobą ściśle związane (s. 10). W kontekście wzajemnej relacji 
między społecznym a ekonomicznym wymiarem transformacji zainteresowany czytelnik powinien zapoznać się z tekstami Jacka Sroki Transformacyjny krajobraz stosunków przemystowych i dialogu spolecznego w Polsce oraz Anny Pankowskiej pt. Finansowa stabilność systemu emerytur jako czesść zabezpieczenia spolecznego. W pierwszym z nich Autor konstatuje, iż m.in. brak kultury politycznej przy równoczesnej zachowawczości uczestników dialogu jest powodem, iż najczęściej nie ma on charakteru dwustronnego, „,bez bezpośredniego zaangażowania władz publicznych" (s. 24). Zdaniem Anny Pankowskiej natomiast niezmiernie ważnymi elementami systemu emerytalnego winna być odpowiednia polityka informacyjna państwa uwypuklająca konieczność oszczędzania w trakcie zarobkowania (s. 57).

Nie sposób przedstawić koherentny obraz 25 lat przemian bez przywołania znaczenia zmian na poziomie regionalnym i lokalnym. Temu zagadnieniu został poświęcony następny z tomów. W zebranych artykułach autorzy podjęli tematykę m.in. z zakresu bezpieczeństwa lokalnego, opisując rolę Komendy Miejskiej Policji w Koszalinie w kreowaniu bezpieczeństwa. Interesującym studium traktującym o wykorzystaniu funduszy unijnych w systemie edukacji na przykładzie partnerskich projektów szkół Comenius, jest tekst Małgorzaty Bielskiej. Studium regionalnym nad dominującymi wartościami społecznymi reprezentowanymi przez młodzież szkół ponadgimnazjalnych w województwie pomorskim i zachodniopomorskim jest artykuł Zbigniewa Werry. Całościowe spojrzenie, oceniające bilans ćwierćwiecza polskiego systemu wyborczego do samorządu terytorialnego zaprezentowała Ewa Włodyka.

Zmiany dla polityki regionalnej wynikające z postępującego zbliżenia z Unią Europejską zaprezentowali z kolei w swoich artykułach Agnieszka Stachura i Tomasz Hoffman. Skoncentrowali się oni w swoich artykułach kolejno na problemie euroregionów jako specyficznej formie polityki regionalnej Unii Europejskiej oraz na europeizacji polityki regionalnej w Polsce.

W tomie poświęconym obliczom zmian regionalnych i lokalnych znalazły się także teksty traktujące o mieście Piła. Pierwszy z nich ukazuje przebieg wyborów kontraktowych w tym mieście, w czerwcu 1989 roku, drugi natomiast koncentruje się na wybranych aspektach rozwoju pilskiego w latach 1999-2013.

Ostatni z tomów Polska w Europie 1989-2014 25 lat po przemianach jest publikacją najobszerniejszą z całego cyklu. Autorzy dotykają w niej problemu płaszczyzn przeobrażeń społeczno-kulturalnych. Zagadnienie to jawi się jako niezmiernie ważne, ponieważ jak autorzy zauważyli we wprowadzeniu, ,spośród funkcjonującej w transformacji triady polityka - gospodarka - społeczeństwo, to ono właśnie jest najsłabszym ogniwem” (s. 5).

W tomie tym dominują teksty dotyczące bezpieczeństwa w miękkim wymiarze, współczesnej roli mediów czy badań nad kulturą i wartościami kulturowymi. Zainteresowany czytelnik odnajdzie interesujące informacje z zakresu polityki społeczno-ekonomicznej, której dotyczą teksty Marka Pogonowskiego o reformie emerytalnej oraz Urszuli Kosowskiej o przemianach modelu rodziny w Polsce. Szczególnie interesujący jest również artykuł Andrzeja Chodubskiego stanowiący diagnozę i ocenę charakteru współczesnej migracji Polaków. Autor słusznie zauważa w nim, iż migracje zagraniczne ,stanowią istotny składnik krajobrazu społeczno-ekonomicznego" rozwiązując wiele współczesnych problemów jak chociażby bezrobocie (s. 50).

Publikacja pod redakcją Jacka Knopka, Małgorzaty Sikory-Gacy i Renaty Gabryszak jest istotnym wkładem w naukową dyskusję dotyczącą bilansu lat 1989-2014. Zgromadzenie artykułów traktujących o podobnej problematyce i wydanie ich w osobnych tomach należy ocenić ze wszech miar pozytywnie. Podjęta w artykułach tematyka jest cały czas aktualna, a jakość zawartych w nich informacji dobra. Autorzy trafnie dobrali wykorzystaną literaturę oraz właściwie przywoływali materiały źródłowe.

RAFAŁ KAMPROWSKI 